\title{
New Evidence of Changes in Students' Achievement Motivation in the Context of the COVID-19 Pandemic
}

Jonathan Smith ( $\sim$ jonathan.smith@usherbrooke.ca )

Université de Sherbrooke

Fanny-Alexandra Guimond

University of Ottawa

Jérôme St-Amand

Université du Québec en Outaouais

Caroline Fitzpatrick

Université de Sherbrooke

Julie Bergeron

Université du Québec en Outaouais

Mathieu Gagnon

Université de Sherbrooke

\section{Short Report}

Keywords: COVID-19 pandemic; achievement motivation; expectancy-value perceptions; high school students

Posted Date: January 28th, 2022

DOI: https://doi.org/10.21203/rs.3.rs-1299567/v1

License: (9) This work is licensed under a Creative Commons Attribution 4.0 International License. Read Full License 


\section{Abstract}

In an article published early in 2021, we shared results indicating that expectancy (i.e., competence beliefs) and value (i.e., interest in learning, utility value, mastery and performance goals) perceptions among a sample of 90 French Canadian students $\left(M_{\text {age }}=14.81\right)$ in grades 9 and 10 remained at similar levels from few weeks before the first wave (January 2020) to the second wave (November 2020) of the COVID-19 pandemic. One perception (i.e., interest) even improved, suggesting that, after experiencing a confinement, students re-approached in-class activities with enthusiasm. To determine if this pattern of results remained the same as the pandemic persisted, an additional measurement has been performed during the third wave. Analysis with this additional data point revealed that interest, utility value and mastery goals ended up declining. These new data suggest that, ultimately, this pandemic has negative effects on students' motivation, even if they keep benefiting from in-class activities.

\section{Introduction}

In a previous article published in January 2021 (Smith et al., 2021), we estimated the effects of the first and the second waves of the COVID-19 pandemic on students' achievement motivation, using an integrative expectancy-value model proposed by Pintrich and Schrauben (1992). We indeed assessed changes in expectancy (i.e., competence beliefs) and value (i.e., interest in learning, utility value of learning, mastery goal orientation and performance goal orientation) perceptions based on data that was collected from a small sample of French Canadian high school students at two time points, namely few weeks before the first positive case of COVID-19 infection was detected in the province of Quebec, Canada (and that province declared a state of emergency) and during the second wave of the pandemic. Findings revealed that student's motivational resources remained somewhat stable in time and that interest in learning even increased. These results, which do not coincide with the usual declining pattern of learning motivation (Fredricks \& Eccles, 2002; Jacobs et al., 2002; Paulick et al., 2013; Watt, 2004) suggested that, when students were allowed to reintegrate school after a prolonged home confinement, they were potentially relieved that they could interact in person again and expressed heightened interest in learning. That being said, these results only represented a snapshot of the pandemic and it is worth wondering if they are not underestimate the long-term potentially damaging effects of the pandemic on student's motivational resources. In an attempt to have a better portray of the effect of this health crisis on students' achievement motivation, the participants were contacted once more. Therefore, we here present the results of this third time point.

\section{Method}

As mentioned, the same method that has been used to make a preliminary estimation of the effects of the COVID-19 pandemic on student achievement motivation was used again (see Smith et al., 2021). The 90 students $\left(M_{\text {age }}=14.81\right)$ in in 9th and 10th grade from two urban public high school in Quebec, Canada, that have been already surveyed with a questionnaire prior to the pandemic (Time 1: January 2020) and during the second wave (Time 2: November 2020), were invited in May 2021 to respond for a 
third time (Time 3). This questionnaire targeted their expectancy and value perceptions and more precisely, their competence beliefs, interest in learning and utility value (with subscales adapted from the work of Ntamakiliro et al., 2000) as well as their mastery and performance goal orientations (with subscales elaborated by Bouffard et al., 1998). It is worth specifying that twelve students did not accept to participate to the follow-up (attrition $=13,3 \%$ ), resulting in a final sample of 78 participants. Item-level missing data were imputed using a multiple imputation method with 25 iterations. Repeated measure multivariate analysis of variance (MANOVA) with time as the repeated measure were conducted.

\section{Results}

As can be seen in Table 1, the repeated-measure MANOVA revealed a significant effect of time $F(10,80)=$ $4.04, p<.001$. Indeed, interest in learning increased from Time $1(M=3.78, S D=0.85)$ to Time $2(M=$ 4.01, $S D=0.85)$, but then decreased at Time $3(M=3.67, S D=0.95)$. A similar pattern of results emerges for utility value which decreased from Time $2(M=4.40, S D=0.82)$ to Time $3(M=4.02, S D=0.92)$ and mastery goal orientation which also decreased from Time $2(M=4.89, S D=0.81)$ to Time $3(M=4.65, S D$ $=0.75)$. 
Table 1

Results of repeated-measure multivariate analyses of variance (MANOVAs)

\begin{tabular}{|c|c|c|c|c|c|}
\hline \multirow[t]{2}{*}{ Variable } & \multicolumn{4}{|c|}{$M(S D)$} & \multirow{2}{*}{$\begin{array}{l}F \text { (Effect size) } \\
\text { Time }\end{array}$} \\
\hline & $\mathrm{T} 1$ & $\mathrm{~T} 2$ & T3 & & \\
\hline \multirow[t]{6}{*}{ Competence beliefs } & 4.61 & 4.66 & 4.52 & $1-2$ & .33 \\
\hline & $(.94)$ & $(.92)$ & $(.84)$ & $1-3$ & $(.00)$ \\
\hline & & & & $2-3$ & .62 \\
\hline & & & & & $(.01)$ \\
\hline & & & & & 2.00 \\
\hline & & & & & $(.02)$ \\
\hline \multirow[t]{6}{*}{ Interest in learning } & 3.78 & 4.01 & 3.67 & $1-2$ & $8.74 \star \star$ \\
\hline & $(.85)$ & $(.85)$ & (.95) & $1-3$ & $(.09)$ \\
\hline & & & & $2-3$ & 1.45 \\
\hline & & & & & $(.02)$ \\
\hline & & & & & $18.42^{\star \star}$ \\
\hline & & & & & $(.17)$ \\
\hline \multirow[t]{6}{*}{ Utility value of learning } & 4.30 & 4.40 & 4.02 & $1-2$ & 1.41 \\
\hline & $(.88)$ & $(.82)$ & $(.92)$ & $1-3$ & $(.02)$ \\
\hline & & & & $2-3$ & $9.91 * \star$ \\
\hline & & & & & $(.10)$ \\
\hline & & & & & $19.19 * \star$ \\
\hline & & & & & $(.18)$ \\
\hline \multirow[t]{6}{*}{ Mastery goal orientation } & 4.76 & 4.89 & 4.65 & $1-2$ & 2.39 \\
\hline & $(.86)$ & $(.81)$ & (.75) & $1-3$ & $(.03)$ \\
\hline & & & & $2-3$ & 1.39 \\
\hline & & & & & $(.02)$ \\
\hline & & & & & $9.76^{\star \star}$ \\
\hline & & & & & $(.10)$ \\
\hline
\end{tabular}




\begin{tabular}{|c|c|c|c|c|c|}
\hline \multirow[t]{2}{*}{ Variable } & \multicolumn{4}{|c|}{$M(S D)$} & \multirow{2}{*}{$\begin{array}{l}F(\text { Effect size) } \\
\text { Time }\end{array}$} \\
\hline & $\mathrm{T} 1$ & $\mathrm{~T} 2$ & T3 & & \\
\hline \multirow[t]{6}{*}{ Performance goal orientation } & 3.43 & 3.35 & 3.48 & $1-2$ & .84 \\
\hline & $(1.27)$ & $(1.20)$ & $(1.17)$ & $1-3$ & $(.01)$ \\
\hline & & & & $2-3$ & .18 \\
\hline & & & & & $(.00)$ \\
\hline & & & & & 2.25 \\
\hline & & & & & $(.03)$ \\
\hline Notes. $n=78, * p<.05, \star \star p<$ & & & & & \\
\hline
\end{tabular}

\section{Discussion}

These results offer new insight on the consequences of the COVID-19 pandemic on students' achievement motivation. Indeed, they highlight the damaging effects that could not been estimated previously as students were still positively reacting to their return to in-presence activities. In our previous study, competence beliefs, utility value of learning, mastery goals and performance goals remained somewhat intact, while interest in learning even increased, however, our new data show that these trends were only temporary. Indeed, in the longer run, not only interest in learning decreased, but so did utility value and mastery goals. These new findings suggest that the pandemic will have damaging effects on students' achievement motivation.

It is difficult to determine whether these changes are due to the pandemic, especially since motivation tends to decline as students progress through grades (Fredricks \& Eccles, 2002; Jacobs et al., 2002; Paulick et al., 2013; Watt, 2004). However, as we already pointed out, several recent studies revealed that students' mental health has been negatively impacted by this pandemic (Guimond et al., 2021; Lane et al., 2021; Rogers et al., 2021; Rothe et al., 2021; Tang et al., 2021; Tardif-Grenier et al., 2021; Vaillancourt et al., 2021) and these findings leave to think that their motivational resources were also negatively impacted.

\section{Conclusion}

The results of this follow-up study seem to be less tinted with the return to school in-person optimism and may reflect better the effects of the COVID-19 pandemic on students' achievement motivation. These new evidence are in line with several recent studies and observations indicating that youth experienced high levels of distress during the COVID-19 pandemic. As a consequence, it is likely that they had difficulties engaging in activities that, in normal circumstances, were salient to them. It remains to be seen if the COVID-19 pandemic will have lasting negative effects on the student's motivational resources. 


\section{Declarations}

Ethics Approval The research ethic committee of the Université de Sherbrooke approved this study.

Participant consent A statement of implied consent was obtained from all participants prior to participation. Conflict of interest The authors declare that they have no competing interests.

\section{References}

1. Bouffard, T., Vezeau, C., Romano, G. U. Y., Chouinard, R., Bordeleau, L., \& Filion, C. (1998). Élaboration et validation du Questionnaire des but en contexte scolaire (QBCS) [Elaboration and validation of the Academic Goals Questionnaire]. Canadian Journal of Behavioural Science/Revue canadienne des sciences du comportement, 30(3), 203-206. https://psycnet.apa.org/doi/10.1037/h0087063

2. Fredricks, J. A., \& Eccles, J. S. (2002). Children's competence and value beliefs from childhood through adolescence: Growth trajectories in two male-sex-typed domains. Developmental psychology, 38(4), 519-533. https://psycnet.apa.org/doi/10.1037/0012-1649.38.4.519

3. Guimond, F.-A., Smith, J. Vitoroulis, I., Aucoin, P., St. John, E., Gardam, O., \& MacLachlan, M. (2021). The role of online schooling, screen-based activities, and parent coping in Canadian children's COVID19-related trauma and anxiety symptoms. Psychiatry International, 2(2), 180190. https://doi.org/10.3390/psychiatryint2020014

4. Jacobs, J. E., Lanza, S., Osgood, D. W., Eccles, J. S., \& Wigfield, A. (2002). Changes in children's selfcompetence and values: Gender and domain differences across grades one through twelve. Child development, 73(2), 509-527. https://doi.org/10.1111/1467-8624.00421

5. Lane, J., Therriault, D., Dupuis, A., Gosselin, P., Smith, J., Ziam, S., Roy, M., Roberge, P., Drapeau, M., Morin, P., Berrigan, F., Thibault, I., \& Dufour, M. (2021). The impact of the COVID-19 pandemic on the anxiety of adolescents in Quebec. Child \& Youth Care Forum. https://doi.org/10.1007/s10566-02109655-9

6. Ntamakiliro, L., Monnard, I., \& Gurtner, J. L. (2000). Mesure de la motivation scolaire des adolescents: construction et validation de trois échelles complémentaires [Measuring school motivation among adolescents, construction and validation of three complementary scales]. L'orientation scolaire et professionnelle, 29(4), 673-693. https://doi.org/10.4000/osp.5788

7. Paulick, l., Watermann, R., \& Nückles, M. (2013). Achievement goals and school achievement: The transition to different school tracks in secondary school. Contemporary Educational Psychology, 38(1), 75-86. https://doi.org/10.1016/j.cedpsych.2012.10.003

8. Pintrich, P. R., \& Schrauben, B. (1992). Students' motivational beliefs and their cognitive engagement in classroom academic tasks. In D. H. Schunk \& J. L. Meece (Eds.), Student Perceptions in the Classroom (pp. 149-183). Erlbaum.

9. Rogers, A. A., Ha, T., \& Ockey, S. (2021). Adolescents' perceived socio-emotional impact of COVID-19 and implications for mental health: Results from a US-based mixed-methods study. Journal of Adolescent Health, 68(1), 43-52. https://doi.org/10.1016/j.jadohealth.2020.09.039 
10. Rothe, J., Buse, J., Uhlmann, A., Bluschke, A., \& Roessner, V. (2021). Changes in emotions and worries during the Covid-19 pandemic: an online-survey with children and adults with and without mental health conditions. Child Adolescent Psychiatry and Mental Health, 15(1), 1-9. https://doi.org/10.1186/s13034-021-00363-9

11. Smith, J., Guimond, F.-A., Bergeron, J., St-Amand, J., Fitzpatrick, C., \& Gagnon, M. (2021). Changes in students' achievement motivation in the context of the COVID-19 pandemic: A function of extraversion/introversion?. Education Sciences, 11(1), 30. https://doi.org/10.3390/educsci11010030

12. Tang, S., Xiang, M., Cheung, T., \& Xiang, Y.-T. (2021). Mental health and its correlates among children and adolescents during COVID-19 school closure: The importance of parent-child discussion. Journal of Affective Disorders, 279, 353-360. https://doi.org/10.1016/j.jad.2020.10.016

13. Tardif-Grenier, K., Archambault, I., Dupéré, V., Marks, A. K., \& Olivier, E. (2021). Canadian adolescents' internalized symptoms in pandemic times: Association with sociodemographic characteristics, confinement habits, and support. Psychiatric Quarterly, 92. https://doi.org/10.1007/s11126-02109895-x

14. Vaillancourt, T., Szatmari, P., Georgiades, K., \& Krygsman, A. (2021). The impact of COVID-19 on the mental health of Canadian children and youth. FACETS, 6(1), 1628-1648. https://doi.org/10.1139/facets-2021-0078

15. Watt,H. M. G. (2004). Development of adolescents' self-perceptions, values, and task perceptions according to gender and domain in 7th-through 11th-grade Australian students. Child development, 75(5),1556-1574. https://doi.org/10.1111/j.14678624.2004.00757.x 